\title{
Vitamin D deficiency, bone turnover markers and causative factors among adolescents: a cross-sectional study
}

\author{
Bagher Larijani, Arash Hossein-Nezhad*, Elham Feizabad, Zhila Maghbooli, Hossein Adibi, Majid Ramezani \\ and Eghbal Taheri
}

\begin{abstract}
Background: This cross-sectional population-based study was conducted to elucidate the prevalence of vitamin D deficiency, bone turnover marker's variation and its influencing factors among adolescents of Tehran.

Methods: Totally 444 middle and high school (53.6 \% in high school) students (both girls and boys) were recruited. A short food frequency questionnaire designed to estimate dietary calcium and vitamin D consumption. Serum levels of calcium, phosphorus, parathyroid hormone (PTH), bone specific alkaline phosphates, $25(\mathrm{OH})$ vitamin $\mathrm{D}$, osteocalcin, cross-linked C-telopeptide (CTX), total protein, albumin and creatinine were determined.

Results: Vitamin D deficiency was prevalent in adolescents and only $22.4 \%$ of students had normal serum vitamin D. Results revealed that vitamin D insufficiency reported in $34.2 \%$ of students and vitamin D deficiency was in 43. $3 \%$ of them. Serum vitamin D, osteocalcin, CTX and bone specific alkaline phosphates were significantly higher in boys in all different ages. Serum levels of $25(\mathrm{OH})$ vitamin D had positive influences on bone turnover markers and had negative correlation with PTH.

Conclusions: Vitamin D deficiency and insufficiency is common among healthy adolescents of Tehran. There is a pressing need to improve vitamin D status among adolescents. Increasing vitamin D fortification of dairy products can be considered as a population-wide public health strategy in Iran.
\end{abstract}

Keywords: Vitamin D deficiency, Bone turnover markers, Adolescents

\section{Background}

As evidences increasingly emphasis that $25(\mathrm{OH})$ vitamin $\mathrm{D}$ deficiency, in addition to its negative impact on bone mineral density status, may contribute to other chronic disease, such as cardiovascular, hypertension, diabetes, cancer, increaces incidence of schizophrenia and depression and some inflammatory and autoimmune diseases, to fight $25(\mathrm{OH})$ vitamin D deficiency in all age groups is a very important measure [1-3].

The prevalence of $25(\mathrm{OH})$ vitamin D deficiency in adolescents is different, but considerably high in many regions, like Middle-east and South-East Asia. High prevalence of $25(\mathrm{OH})$ vitamin D deficiency in Iran is

\footnotetext{
* Correspondence: arash_hsi@yahoo.com

Osteoporosis Research Center, Endocrinology and Metabolism Clinical Sciences Institute, Tehran University of Medical Sciences, 5th floor, shariati Hospital, North Kargar, Tehran 141142386, Iran
}

similar to the results of other studies in Middle East areas, $75.1 \%$ of women and $72.1 \%$ of men in Iran have different level of $25(\mathrm{OH})$ vitamin D deficiency $[4,5]$.

In addition to high prevalence of $25(\mathrm{OH})$ vitamin $\mathrm{D}$ deficiency in Iranian adult, $25(\mathrm{OH})$ vitamin D deficiency in Iranian adolescents is common for an example, prevalence of $25(\mathrm{OH})$ vitamin D deficiency in Tehran adolescent is $53.6 \%$ in girls and $11.3 \%$ in boys. $25(\mathrm{OH})$ vitamin $\mathrm{D}$ deficiency in female students was about five times more common than male students [6-8].

In children and adolescents $25(\mathrm{OH})$ vitamin D deficiency is more important because development of peak bone mass happens in these critical ages and any adverse effects due to low $25(\mathrm{OH})$ vitamin D and low calcium level will influence in their later lifelong $[9,10]$. For example, one of the factors that can decrease the chance 
of osteoporosis in old ages is peak bone mass during childhood and adolescence [11].

Also, $25(\mathrm{OH})$ vitamin D deficiency can have adverse effects on bone health. It is well known that prolonged $25(\mathrm{OH})$ vitamin D deficiency (serum $25(\mathrm{OH})$ vitamin D concentrations $<10-25 \mathrm{nmol} / \mathrm{L}$ ) can cause rickets in children and osteomalacia in adults. Although, the influence of subclinical $25(\mathrm{OH})$ vitamin D deficiency or 25 $(\mathrm{OH})$ vitamin D insufficiency on skeletal health is less obvious [12].

It is well-established that, in elderly people, low 25 $(\mathrm{OH})$ vitamin D status increases parathyroid hormone (PTH) concentrations in serum, that causes bone turnover and bone loss, defects mineralization, and increases risk of fractures of bones [13]. But the effect of increasing PTH in children and adolescents is unclear [12]. For example, serum PTH concentration is normally higher during adolescence $[14,15]$.

Bone formation marker, Osteocalcin and a new marker of bone resorption, carboxyl terminal telopeptide of type I collagen (CTX) [11] can help us to understand more about what happen during $25(\mathrm{OH})$ vitamin D deficiency in adolescents.

According to the above-mentioned facts and low available evidences, the present study was done to assess the level of serum $25(\mathrm{OH})$ vitamin $\mathrm{D}$ and bone turnover markers and other contributing bone health in adolescents lived in Tehran.

\section{Method}

The cross-sectional study is conducted on guidance and high school students of both genders from different districts of Tehran, the Iranian capital, in wintertime to assess the level of serum $25(\mathrm{OH})$ vitamin $\mathrm{D}$ and bone turnover markers and other contributing bone health.

From 36 schools of 5 different district of Tehran, Three middle schools and three high schools for boys were randomly selected from the list. A similar strategy was used to select the girl schools. The selected schools were distributed in five different regions of Tehran Municipality including 3,10,11,16, and 17. Students studying in region three included $27.3 \%$ of participants, region ten $8.3 \%$, region eleven $25.9 \%$, region sixteen $20 \%$, region seventeen $18.5 \%$.

This research was carried out in compliance with the Helsinki Declaration and approved by ethics committee, Institute of Endocrinology and Metabolism, Tehran University of Medical Sciences. All the parents sign an informed consent.

Inclusion criteria included all subjects that educated in these selected schools and their parents signed informed consent form and the students themselves tend to participate in our study. Exclusion criteria included students who have taken vitamin D supplements (different forms of Calcium and Vitamin D supplements or multivitamins containing Calcium and Vitamin D) during the past 3 months, suffering from underlying conditions (liver, kidney, gastrointestinal, cancer, endocrine, bone and biliary disease) or consuming medication affecting bone metabolism (anti-convulsants, anti-tuberculosis medication, HMG-CoA inhibitors, cimetidine, theophylline, and cholestyramine), as well as those who are following special diets such as vegetarian diet or consuming fortified products regularly.

Approximately $10 \mathrm{cc}$ of blood was drawn between 7:00 A. M. and 9:30 A. M. after the student had fasted for at least eight hours. Blood samples were used to determine calcium, phosphorus, bone specific alkaline phosphatase, $25(\mathrm{OH}) \mathrm{D}$, osteocalcin, cross-linked C-telopeptide (CTX), total protein, albumin and creatinine. Blood samples were taken in a sitting position according to the standard protocol. Participants rested in the seated position for $15 \mathrm{~min}$ prior to blood collection. This waiting period allowed calibration of the concentrations of blood components. The vacuum tubes were immediately placed on wet ice and transferred to the EMRI laboratory for centrifugation (at $3000 \mathrm{rpm}$ for $10 \mathrm{~min}$ ).

Blood samples were aliquoted into four vials for freezing at $-70{ }^{\circ} \mathrm{C}$ until assayed. Calcium (Man, Arsenazo), phosphorus (Man, Phosphomolybdate, UV), albumin (Pars Azmoon, Bromocresol Green), total protein (Pars Azmoon, Biuret), creatinine (Man, Jaffe Kinetic), and alkaline phosphatase (Pars Azmoon, DGKC) were determined with inter assay coefficient variation $(\mathrm{CV})$ of 3.9, 6 , 2.2, 3, 4.5 and $2.1 \%$ respectively. Intact PTH was measured by Immunoradio Metric Assay (IMMUNOTECH) with CV of $6.6 \%$. Vitamin D, Osteocalcin (N- MID), CTX (Immunodiagnostic systems) were measured by Enzyme Immunoassay with CV\% of 9, 8, 6 and $10 \%$ respectively. All the samples with high concentration of analytes (more than reportable ranges) were diluted according to kit protocol and assessed again. The normal ranges of blood vitamin D for adolescents considered $>30 \mathrm{ng} / \mathrm{ml}$. Serum 25-hydroxyvitamin $20 \leq \mathrm{D} \leq 30 \mathrm{ng} / \mathrm{ml}$ considered as vitamin $\mathrm{D}$ Insufficiency and serum 25-hydroxy vitamin $\mathrm{D}<20 \mathrm{ng} / \mathrm{ml}$ as vitamin $\mathrm{D}$ deficiency. The normal ranges of blood calcium for adolescents considered 6.7-10.7 $\mathrm{mmol} / \mathrm{L}$.

The students are then asked to fill a questionnaire on their demographic data, possible underlying diseases and bone health-related lifestyle habits. They also asked to fill a weekly questionnaire on their compliance with milk consumption and possible reasons for not consuming milk regularly. Also, a short food frequency questionnaire designed to estimate dietary calcium and vitamin $\mathrm{D}$ consumption in the past 3 months.

Finally, the data were analyzed with SPSS version 19. T-test, ANOVA and Spearman correlations tests were 
used. We use parametric tests because the numbers of students in each group of analyses were more than thirty. $P$ value less than 0.05 was considered to be statistically significant.

\section{Result}

The total number of participations were 444 people and the number of girls and boys were approximately equal (48.2 vs. $51.8 \%$ ). The average age of them was 14.34 and about $46.4 \%$ of them were studying in middle school and $53.6 \%$ in high school.

The average calcium intake in boys' daily diet was $1240.2 \mathrm{mg}( \pm 72.45)$ while this was $1108.05 \mathrm{mg}( \pm 62.34)$ in girls but about $40 \%$ in each sex groups consumed calcium below $700 \mathrm{mg}$ per day. The mean daily vitamin D intake in boys was 1.42 microgram $( \pm 0.08)$ and in girls was 1.29 microgram $( \pm 0.08)$.

The average of serum calcium was $9.93 \mathrm{mg} / \mathrm{dl}( \pm 0.02)$ and the minimum of calcium level was $8.10 \mathrm{mg} / \mathrm{dl}$ and it showed that no students had below normal calcium level whereas only $22.4 \%$ of them had normal ranges of serum $25(\mathrm{OH})$ vitamin D.

The mean of serum $25(\mathrm{OH})$ vitamin D was $25.82 \mathrm{ng} /$ $\mathrm{ml}( \pm 0.74)$ and the minimum of $25(\mathrm{OH}) \mathrm{D}$ was $4.37 \mathrm{ng} /$ dl. About $34.2 \%$ of students had $25(\mathrm{OH})$ vitamin D Insufficiency (serum 25-hydroxyvitamin $20 \leq \mathrm{D} \leq 30 \mathrm{ng}$ / $\mathrm{ml}$ ) and $43.3 \% 25(\mathrm{OH})$ vitamin D deficiency (serum 25 -hydroxy vitamin $\mathrm{D}<20 \mathrm{ng} / \mathrm{ml}$ ). Also, the prevalence of $25(\mathrm{OH})$ vitamin D deficiency was showed separately according to different genders in Fig. 1.

The level of $25(\mathrm{OH})$ D was significantly higher among boys rather than girls, $31.32 \mathrm{ng} / \mathrm{ml}$ vs $19.89 \mathrm{ng} / \mathrm{ml}$ while the level of serum calcium higher in girls.

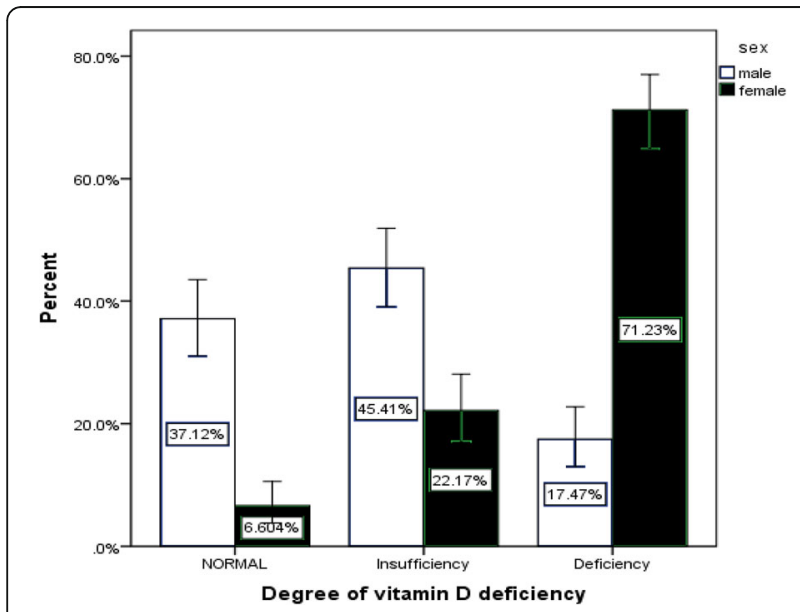

Fig. 1 The prevalence of $25(\mathrm{OH})$ vitamin $D$ deficiency in different genders. $25(\mathrm{OH})$ vitamin D normal range: serum $25(\mathrm{OH}) \mathrm{D}>30 \mathrm{ng} /$ ml. $25(\mathrm{OH})$ vitamin D Insufficiency: serum $25(\mathrm{OH})$ D $20 \leq \mathrm{D} \leq$ $30 \mathrm{ng} / \mathrm{ml} .25(\mathrm{OH})$ vitamin D Insufficiency: serum $25(\mathrm{OH})$ D $20 \leq \mathrm{D} \leq 30 \mathrm{ng} / \mathrm{ml}$
We assessed bone mass markers in boys and girls separately in age $\leq 14$ years and age $>14$ years (because this age separates middle and high school students and also, most girls come in puberty stages before the age of 14, while most boys come in puberty stages after this age). Serum $25(\mathrm{OH})$ vitamin D, osteocalcin, CTX and bone specific alkaline phosphates were significantly higher in boys in two categories of ages and Parathyroid hormone had a significant different between boys and girls but with higher level in girls (Table 1).

A negative significant correlation between serum 25 $(\mathrm{OH})$ vitamin D and PTH was detected. Also, there was a significant positive correlation between serum $25(\mathrm{OH})$ vitamin D and osteocalcin, CTX, bone specific alkaline phosphates (Fig. 2). As was shown in Fig. 2, with increasing in serum $25(\mathrm{OH})$ vitamin $\mathrm{D}$, bone turnover markers increased. Also, the mean of each bone markers, can be significantly altered based on changing in serum 25 $(\mathrm{OH})$ vitamin D categories that was shown in Table 2.

\section{Discussion}

The present study showed that $25(\mathrm{OH})$ vitamin D deficiency in Tehran healthy adolescents, was common and it was about $43.3 \%$, with higher rates in girls by $71.23 \%$ rather than boys by $17.47 \%$ and it was near to previous study that was assessed the prevalence of $25(\mathrm{OH})$ vitamin D deficiency in Tehran adolescents. In that study, Prevalence of serum $25(\mathrm{OH})$ vitamin $\mathrm{D}<20 \mathrm{ng} / \mathrm{ml}$ was $53.6 \%$ in girls and $11.3 \%$ in boys [16].

Also, our study showed that in female adolescents, 25 $(\mathrm{OH})$ vitamin $\mathrm{D}$ deficiency, was about four times more prevalent than males $(p<0.001)$, it was constant with previous reports and need to attention to this major health problem, not just for female adolescents, also for next generations $[16,17]$.

Different factors may cause $25(\mathrm{OH})$ vitamin D deficiency in Tehran adolescents, as Middle East habitants, despite its abundant sunshine, they are more susceptible to25 $(\mathrm{OH})$ vitamin D deficiency [18]. In addition to Iran, low serum 25(OH) D levels had been reported in the different region of Middle East, for example, Turkey, Lebanon and Jordan, also, in these countries serum 25 $(\mathrm{OH})$ vitamin $\mathrm{D}$ was lower in women rather than in men. It is worth to mention that the immigrants in Europe that come from Middle East and Asia carry a high risk for $25(\mathrm{OH})$ vitamin D deficiency [19].

Synthesis of $25(\mathrm{OH})$ vitamin D in the skin is very important and it contains about $90 \%$ of all the body's needs [20], but many determinants can influence in the synthesis of $25(\mathrm{OH})$ vitamin $\mathrm{D}$ in the skin including exposure to UVB solar radiation, winter season, sunscreen use, being indoors [21-23]. Tehran is a mega city with polluted air. Air pollution is one of the main elements influences in the percentage of the ground level UVB. The 
Table 1 The Mean \pm SE of bone markers and serum biomarkers according by age, sex

\begin{tabular}{|c|c|c|c|c|c|c|}
\hline & \multirow{2}{*}{$\begin{array}{l}\text { Boys } \leq 14 \mathrm{YO} \\
N=124\end{array}$} & \multicolumn{2}{|l|}{ Girls $\leq 14 \mathrm{YO}$} & \multirow{2}{*}{$\begin{array}{l}\text { Boys }>14 \mathrm{YO} \\
N=106\end{array}$} & \multicolumn{2}{|l|}{ Girls $<14 \mathrm{YO}$} \\
\hline & & $N=105$ & $\begin{array}{l}P \text {-value } \\
\text { (t-test) }\end{array}$ & & $N=109$ & $\begin{array}{l}P \text {-value } \\
(t \text {-test })\end{array}$ \\
\hline Calcium (mg/dL) & $9.91 \pm 0.05$ & $10.00 \pm 0.05$ & 0.216 & $9.81+0.05$ & $9.99+0.04$ & 0.013 \\
\hline Phosphorus (mg/dL) & $5.03 \pm 0.05$ & $4.44 \pm 0.06$ & $<0.001$ & $4.48 \pm 0.06$ & $4.06 \pm 0.05$ & $<0.001$ \\
\hline $25(\mathrm{OH}) \mathrm{D}(\mathrm{ng} / \mathrm{mL})$ & $33.94 \pm 1.38$ & $19.65 \pm 1.64$ & $<0.001$ & $28.27+1.30$ & $20.12+1.12$ & $<0.001$ \\
\hline Parathyroid hormone (pg/mL) & $50.29 \pm 3.46$ & $92.66 \pm 9.45$ & $<0.001$ & $36.18+2.01$ & $43.29+2.40$ & 0.025 \\
\hline Osteocalcin (ng/mL) & $91.02 \pm 3.29$ & $59.93 \pm 2.04$ & $<0.001$ & $65.99+3.23$ & $25.67+1.17$ & $<0.001$ \\
\hline CTX $(p g / m L)$ & $1.76 \pm 0.06$ & $1.01 \pm 0.05$ & $<0.001$ & $1.45+0.06$ & $0.49+0.02$ & $<0.001$ \\
\hline Bone specific alkaline phosphates (mcg/L) & $251.57+9.59$ & $174.17+12.76$ & $<0.001$ & $138.59+9.23$ & $43.81+1.28$ & $<0.001$ \\
\hline Albumin (g/dL) & $5.38 \pm 0.02$ & $5.24 \pm 0.02$ & 0.001 & $5.24 \pm 0.03$ & $5.17 \pm 0.02$ & 0.095 \\
\hline Total protein (g/dL) & $8.30 \pm 0.04$ & $7.72 \pm 0.05$ & $<0.001$ & $8.23 \pm 0.04$ & $7.76 \pm 0.04$ & $<0.001$ \\
\hline Creatinine (mg/dL) & $0.80 \pm 0.01$ & $0.75 \pm 0.01$ & 0.002 & $0.92 \pm 0.01$ & $0.88 \pm 0.008$ & 0.051 \\
\hline
\end{tabular}

SE standard error of mean, YO years old, CTX cross-linked C-telopeptide

level of air pollution is negatively associated to the amount of solar UVB that reaches earth surface, as a result, more pollutant areas, less UVB passage and consequently, 25 $(\mathrm{OH})$ vitamin D cutaneous syntheses reduces [24].

Natural dietary sources of $25(\mathrm{OH})$ vitamin D are very few and foods that are fortified with $25(\mathrm{OH})$ vitamin $\mathrm{D}$ are often inadequate to satisfy either a child's or an adult's $25(\mathrm{OH})$ vitamin $\mathrm{D}$ requirement $[3,25]$.
On the other hand, adolescence is critical ages to skeletal growth and reach to optimal peak bone mass. The enough intake of calcium and $25(\mathrm{OH})$ vitamin $\mathrm{D}$ from daily dietary, in addition to the normal serum range of calcium and $25(\mathrm{OH})$ vitamin $\mathrm{D}$, has positive effects on bone in adolescents. For example, milk consumption positively correlates with bone mineral density of the total body, spine and radius in adolescent girls [26-29].
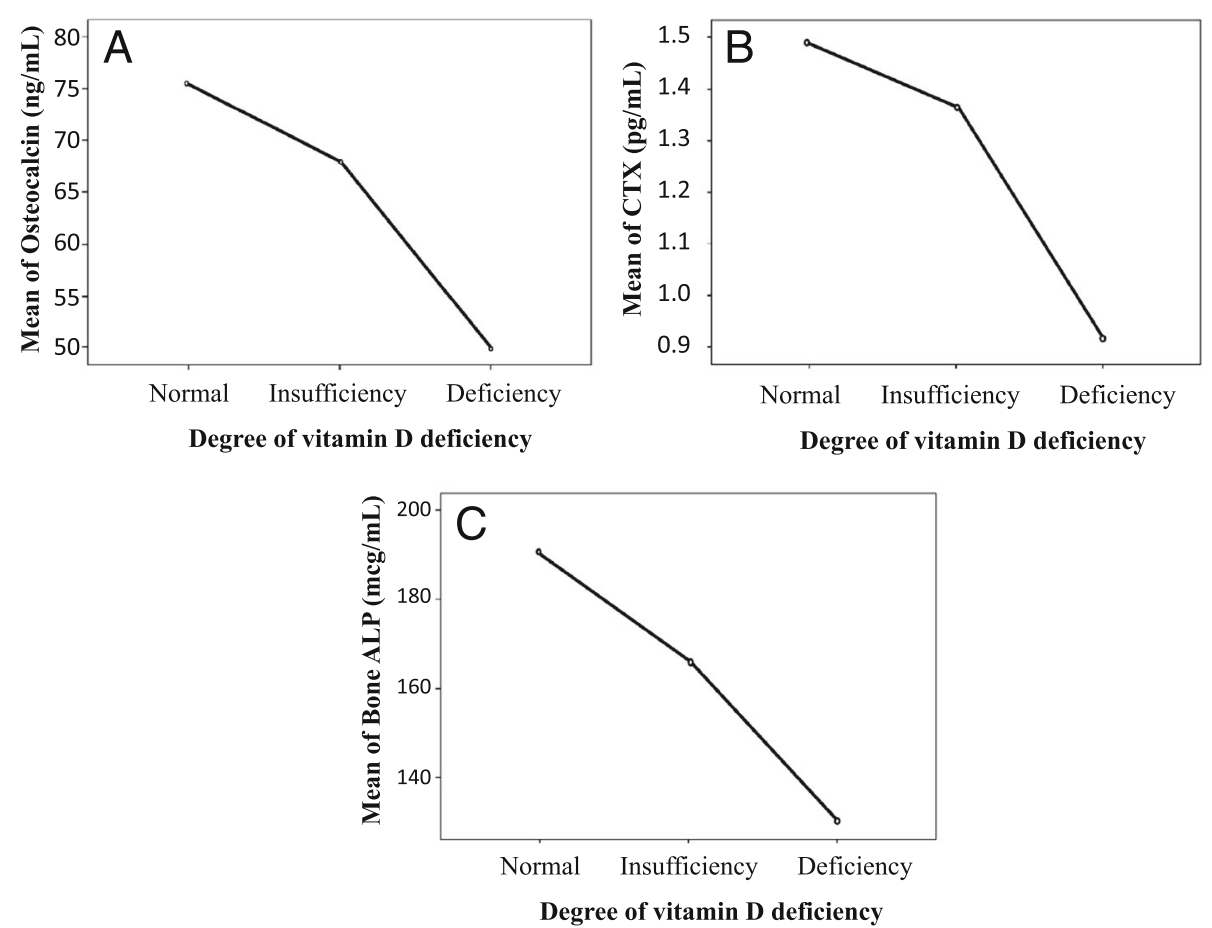

Fig. 2 Osteocalcin (a), CTX (b), Bone alkaline phosphatase (c) trends in different serum $25(\mathrm{OH})$ vitamin D categories.25 (OH) vitamin D normal range: serum $25(\mathrm{OH}) \mathrm{D}>30 \mathrm{ng} / \mathrm{ml}, 25(\mathrm{OH})$ vitamin D Insufficiency: serum $25(\mathrm{OH}) \mathrm{D} 20 \leq \mathrm{D} \leq 30 \mathrm{ng} / \mathrm{ml}, 25(\mathrm{OH})$ Vitamin D deficiency: serum 25 $(\mathrm{OH}) \mathrm{D}<20 \mathrm{ng} / \mathrm{ml}$. CTX: cross-linked C-telopeptide. Bone ALP: Bone alkaline phosphatase 
Table 2 P-value measurement (ANOVA Post Hoc test*) between bone markers level and $25(\mathrm{OH})$ vitamin D different categories

\begin{tabular}{lccc}
\hline Bone markers & \multicolumn{3}{l}{$\begin{array}{l}\text { P-value between bone markers level and } 25(\mathrm{OH}) \\
\text { vitamin D different categories(ANOVA Post Hoc test) }\end{array}$} \\
\cline { 2 - 4 } & $\begin{array}{l}\text { Normal range } \\
\text { with Insufficiency }\end{array}$ & $\begin{array}{l}\text { Normal range } \\
\text { with deficiency }\end{array}$ & $\begin{array}{l}\text { Deficiency with } \\
\text { Insufficiency }\end{array}$ \\
\hline Osteocalcin & 0.291 & $<0.001$ & $<0.001$ \\
CTX & 0.42 & $<0.001$ & $<0.001$ \\
$\begin{array}{l}\text { Bone alkaline } \\
\text { phosphatase }\end{array}$ & 0.31 & $<0.001$ & 0.03 \\
\hline
\end{tabular}

*: As number of students in each of groups of vitamin $D$ deficiency were more than 30 and Test of Homogeneity of Variances was nonsignificant $(>0.05)$

Scheffe Post Hoc was used, $p$-value was significant at $<0.05$

Considering the above-mentioned facts, increasing vitamin $\mathrm{D}$ fortification of dairy products can be recommended as a population-wide public health strategy to fight 25 $(\mathrm{OH})$ vitamin D deficiency especially in adolescents.

As it was shown in our study, there was a significant positive correlation between serum $25(\mathrm{OH})$ vitamin D with osteocalcin, cross laps, bone specific alkaline phosphates. While Bone markers assessment and it's associations is rare in other last studies.

In adult, increasing in serum $25(\mathrm{OH})$ vitamin D suppresses serum PTH and decreasing serum $25(\mathrm{OH})$ vitamin D increases serum PTH concentrations, but the effects of increasing in PTH in children and adolescents are unclear, although in our study, a negative significant correlation was detected between serum $25(\mathrm{OH})$ vitamin D and PTH in adolescents [12, 1, 13].

One of things, that could confounded our result was, not excluding students with positive history of use any supplements consuming or any underlying diseases after sampling (9 students consumed different forms of Calcium and Vitamin D supplements, 1 person had jaundice in face and hands, 1 person kidney stones, 4 students gastrointestinal disorder, 5 students thyroid disorder and 1 person had rickets. one person had seizure disorder and consumed valproate sodium, one person used atorvastatin and two people consumed corticosteroid drugs), but we try to find these not correct reports of these students with double checking and minimize their confounded effects. Also, due to the small sample size, our study could not be representieveness of all Tehran adolescents, although, our study had an acceptable power in determining the prevalence of vitamin D deficiency.

The present study had some limitations. In this study, only adolescents living in the city have been studied. Further research might explore adolescents living in rural areas to determine the amount of Vitamin D and calcium deficiency and bone health biomarkers levels. Furthermore, the impact of this suboptimal vitamin D status on bone health in both population subgroups needs to be investigated. This study was more comprehensive than earlier research and collected data on PTH, and biomarkers of bone formation and resorption in relation to vitamin D status that were not previously evaluated. Hence, data obtained in the present study gives a comprehensive insight into the influence of vitamin $\mathrm{D}$ status and biochemical markers of bone turnover in Tehran's adolescent, after taking into consideration other known factors such as Food habits, the amount of vitamin D intake and lifestyle-related factors.

The findings of the present study show that suboptimal vitamin D status and $25(\mathrm{OH})$ vitamin D deficiency is very common in Tehran's adolescents. It can have adverse effects on bone health, especially in these sensitive ages. Also, the results of this study indicate that $25(\mathrm{OH})$ vitamin D deficiency in female adolescents was about four times more prevalent than males. It is becoming increasingly clear that the fundamental unit for nutrition is the food (eg, milk, nuts, eggs), not the nutrient (e.g., calcium, saturated fat, cholesterol). A nutrient perceived as beneficial, such as calcium, may be unhealthy if the parent food, say milk, contains other nutrients, such as galactose, that on the balance might stimulate adverse effects in the body. In theory, consuming calcium-rich foods such as bones, fermented dairy (e.g., unsweetened yogurt, kefir, and cheese), leafy greens, almonds, and chia seeds may be an effective strategy for improving both calcium intake and long-term health. With regard to results of this study, vitamin D supplementation was associated with the absence of severe deficiency and considerably lowered the prevalence of marginal deficiency of vitamin $\mathrm{D}$ in adolescents in the present study.

\section{Conclusions}

Vitamin D deficiency and insufficiency is common among healthy adolescents of Tehran. There is a pressing need to improve vitamin D status among adolescents. Increasing vitamin $\mathrm{D}$ fortification of dairy products can be considered as a population-wide public health strategy in Iran.

\section{Abbreviations \\ $25(\mathrm{OH})$ D: 25 hydroxy vitamin D; CTX: Cross-linked C-telopeptide}

\section{Acknowledgement}

Not applicable.

\section{Funding}

Funding for this project was provided by Osteoporosis Research Center.

\section{Availability of data and materials}

Data on which this article is based are available from the authors on request.

\section{Authors' contributions}

BL carried out supervising the study and writing paper. AH carried out designing the study, supervising the study, data collection, statistical analysis and writing paper. EF carried out data collection, statistical analysis and writing paper. ZM carried out data collection, statistical analysis and writing paper. HA carried out supervising the study, data collection and writing paper. MR, data collection and writing paper. ET participated in the writing paper. All authors read and approved the final manuscript. 


\section{Competing interest}

The authors declare that they have no competing interests.

\section{Consent for publication}

Informed consent was obtained from all patients for being included in the study.

\section{Ethics approval and consent to participate}

This research was carried out in compliance with the Helsinki Declaration and approved by ethics committee, Institute of Endocrinology and Metabolism, Tehran University of Medical Sciences.

\section{Statement of human and animal rights}

This research was carried out in compliance with the Helsinki Declaration and approved by ethics committee, Institute of Endocrinology and Metabolism, Tehran University of Medical Sciences. All procedures followed were in accordance with the ethical standards of the responsible committee on human experimentation (institutional and national) and with the Helsinki Declaration.

Received: 6 July 2016 Accepted: 1 October 2016

\section{Published online: 12 October 2016}

\section{References}

1. Cashman KD. Vitamin D in childhood and adolescence. Postgrad Med J. 2007:83:230-5.

2. Holick MF. Vitamin D deficiency. N Engl J Med. 2007;357:266-81.

3. Baiz N, Dargent-Molina P, Wark JD, Souberbielle JC, Slama R, AnnesiMaesano I. Gestational exposure to urban air pollution related to a decrease in cord blood vitamin d levels. J Clin Endocrinol Metab. 2012;97:4087-95.

4. Moradzadeh K, Larijani B, Keshtkar A, Hossein-Nezhad A, Rajabian R, Nabipour I, Omrani G, Bahrami A, Gooya M, Delavari A. Normative values of vitamin D among Iranian population: a population based study. Int J Osteoporosis Metab Disord. 2008;1:8-15.

5. Soliman AT, De Sanctis V, Elalaily R, Bedair S, Kassem I. Vitamin D deficiency in adolescents. Indian J Endocrinol Metab. 2014;18:S9-s16.

6. Moussavi M, Heidarpour R, Aminorroaya A, Pournaghshband Z, Amini M. Prevalence of vitamin D deficiency in Isfahani high school students in 2004. Horm Res Paediatr. 2005:64:144-8.

7. Rabbani A, Alavian S-M, Motlagh ME, Ashtiani MT, Ardalan G, Salavati A, Rabbani B, Rabbani A, Shams S, Parvaneh N. Vitamin D insufficiency among children and adolescents living in Tehran, Iran. J Trop Pediatr. 2009;55:189-91.

8. Hashemipour S, Larijani B, Adibi H, Javadi E, Sedaghat M, Pajouhi M, Soltani A, Shafaei AR, Hamidi Z, Fard AR. Vitamin D deficiency and causative factors in the population of Tehran. BMC Public Health. 2004;4:38.

9. Greer FR, Krebs NF. Optimizing bone health and calcium intakes of infants, children, and adolescents. Pediatrics. 2006:117:578-85.

10. Rizzoli R, Bianchi ML, Garabédian M, McKay HA, Moreno LA. Maximizing bone mineral mass gain during growth for the prevention of fractures in the adolescents and the elderly. Bone. 2010;46:294-305.

11. Lehtonen-Veromaa MK, Mottonen T, Nuotio IO, Irjala KM, Leino AE, Viikari JS. Vitamin D and attainment of peak bone mass among peripubertal Finnish girls: a 3-y prospective study. Am J Clin Nutr. 2002;76(6):1446-53.

12. Cashman KD, Hill TR, Cotter AA, Boreham CA, Dubitzky W, Murray L, Strain J, Flynn A, Robson PJ, Wallace JM, Kiely M. Low vitamin D status adversely affects bone health parameters in adolescents. Am J Clin Nutr. 2008;87(4):1039-44.

13. Lips P. Vitamin D deficiency and secondary hyperparathyroidism in the elderly: consequences for bone loss and fractures and therapeutic implications. Endocr Rev. 2001;22:477-501.

14. Krabbe S, Transbøl I, Christiansen C. Bone mineral homeostasis, bone growth, and mineralisation during years of pubertal growth: a unifying concept. Arch Dis Child. 1982;57:359-63.

15. Cadogan J, Blumsohn A, Barker ME, Eastell R. A longitudinal study of bone gain in pubertal girls: anthropometric and biochemical correlates. J Bone Miner Res. 1998;13:1602-12.

16. Rabbani A, Alavian SM, Motlagh ME, Ashtiani MT, Ardalan G, Salavati A, Rabbani B, Rabbani A, Shams S, Parvaneh N. Vitamin D insufficiency among children and adolescents living in Tehran, Iran. J Trop Pediatr. 2009:55:189-91.
17. Razzaghy-Azar M, Shakiba M. Assessment of vitamin D status in healthy children and adolescents living in Tehran and its relation to iPTH, gender, weight and height. Ann Hum Biol. 2010;37:692-701.

18. Fuleihan GE. Vitamin D Deficiency in the Middle East and its Health Consequences for Children and Adults. Clinic Rev Bone Miner Metab. 2009;7:77.

19. Lips P. Vitamin D status and nutrition in Europe and Asia. J Steroid Biochem Mol Biol. 2007;103:620-5.

20. Hosseinpanah F, Sima H, Heibatollahi M, Moghbel N, Asefzade S, Azizi $F$. The effects of air pollution on vitamin D status in healthy women: a cross sectional study. BMC Public Health. 2010;10:519.

21. Langlois K, Greene-Finestone L, Little J, Hidiroglou N, Whiting S. Vitamin D status of Canadians as measured in the 2007 to 2009 Canadian Health Measures Survey. Health Rep. 2010;21(1):47-55.

22. Brown AJ, Dusso A, Slatopolsky E. Vitamin D. Am J Physiol. 1999:277(2):157-75.

23. Tsiaras WG, Weinstock MA. Factors influencing vitamin D status. Acta Derm Venereol. 2011:91:115-24.

24. Hosseinpanah F, Pour SH, Heibatollahi M, Moghbel N, Asefzade S, Azizi F. The effects of air pollution on vitamin D status in healthy women: a cross sectional study. BMC Public Health. 2010;10:519.

25. Holick MF, Chen TC. Vitamin D deficiency: a worldwide problem with health consequences. Am J Clin Nutr. 2008:87(4):1080s-6s.

26. Harkness L, Bonny A. Calcium and vitamin D status in the adolescent: key roles for bone, body weight, glucose tolerance, and estrogen biosynthesis. J Pediatr Adolesc Gynecol. 2005;18:305-11.

27. Chan GM, Hoffman K, McMurry M. Effects of dairy products on bone and body composition in pubertal girls. J Pediatr. 1995;126:551-6.

28. Teegarden D, Lyle RM, Proulx WR, Johnston CC, Weaver CM. Previous milk consumption is associated with greater bone density in young women. Am J Clin Nutr. 1999;69(5):1014-7.

29. Peters B, Verly Jr E, Marchioni D, Fisberg M, Martini L. The influence of breakfast and dairy products on dietary calcium and vitamin D intake in postpubertal adolescents and young adults. J Hum Nutr Diet. 2012:25:69-74.

\section{Submit your next manuscript to BioMed Central and we will help you at every step:}

- We accept pre-submission inquiries

- Our selector tool helps you to find the most relevant journal

- We provide round the clock customer support

- Convenient online submission

- Thorough peer review

- Inclusion in PubMed and all major indexing services

- Maximum visibility for your research

Submit your manuscript at www.biomedcentral.com/submit
Biomed Central 